\title{
Kemampuan Representasi Matematis Siswa Pada Materi Kesebangunan
}

\author{
Khoirunisa Aisha Sabrina*, Kiki Nia Sania Effendi \\ Pendidikan Matematika, Universitas Singaperbangsa Karawang, Karawang, Indonesia \\ *Coresponding Author: 1810631050127@student.unsika.ac.id
}

Article History:

Received 2022-01-27

Revised 2022-02-19

Accepted 2022-03-01

DOI:

10.31949/educatio.v8i1.1969

\begin{abstract}
This research aims to know students' mathematical representation ability in solving the problem on the congruence material. This research uses a descriptive method and a qualitative approach. The subjects of this research were the students of class $X$ in one of the Madrasah Aliyah in Kecamatan Purwasari, kabupaten Karawang; as many as three students were selected from 10 students. Research subjects were determined using the purposive sampling method. The instrument used is a mathematical representation ability test on the congruence material containing five description questions. This research indicates that the research subject at that school is the students' mathematical representation ability which is classified as average categories. The results show that students in low categories achieved one indicator there is verbal representation ability. The students in average categories completed two indicators: verbal and reciprocal mathematical representation ability indicators. In contrast, the students in high categories achieved three indicators: verbal, reciprocal, and symbolic mathematical representation ability.

Keywords: mathematical representation ability, congruence; math learning
\end{abstract}

\section{PENDAHULUAN}

Pendidikan merupakan suatu aspek penting yang mampu mendukung terbentuknya pola pikir siswa agar berguna dalam kehidupan sehari-hari, salah satu pembelajaran yang akan mewujudkan hal tersebut adalah matematika. Annajmi (2016) menuturkan bahwa matematika mampu meningkatkan kemampuan berpikir siswa. Oleh karena itu, kemampuan tersebut dapat terbentuk jika siswa terbiasa menghadapi permasalahan matematika. Sejalan dengan penuturan Hendrayana (2017) bahwa kemampuan matematis mampu menjadikan seseorang kompetitif menghadapi masalah sulit karena memperoleh pelajaran matematika.

Dalam pelajaran matematika, tentunya akan melibatkan kemampuan kemampuan matematis untuk mencapai tujuan pembelajaran. NCTM (2000) menetapkan terdapat lima standar utama tujuan pembelajaran 
matematika diantaranya kemampuan representasi. Kemampuan representasi matematis adalah kemampuan yang dimiliki oleh siswa untuk menggagaskan suatu ide matematika dalam berbagai bentuk pernyataan. Kemampuan representasi melibatkan penerjamahan informasi yang diberikan oleh suatu masalah ke dalam bentuk lain. Oleh karenanya, kemampuan representasi menjadi hal yang sangat penting untuk dimiliki karena mampu membantu siswa dalam penyelesaian masalah matematika. Sejalan dengan penuturan Handayani dan Juanda (2018) bahwa kemampuan representasi menjadi alat bantu untuk siswa dalam menyelesaikan masalah matematika. Nadia, ST, dan Isnarto (2017) menegaskan kemampuan representasi menjadi suatu hal yang wajib dimiliki selama proses penyelesaian masalah matematika.

Penyelesaian masalah matematika secara mudah diselesaikan jika melibatkan kemampuan representasi karena kemampuan tersebut mampu membantu siswa dalam memahami dan mengaitkan konsep matematika. Inayah dan Nurhasanah (2019) menuturkan bahwa siswa yang memiliki kemampuan tersebut akan menyajikan masalah dengan bentuk pengganti. Bentuk pengganti tersebut merupakan hasil dari pemikirannya. Sejalan dengan Huda, Musdi, dan Nari (2019) yang menuturkan bahwa siswa dengan kemampuan tersebut mampu mencetuskan hasil pemikiran matematikanya dari permasalahan yang sedang dihadapi.

Absorin dan Sugiman (2018) menegaskan bahwa permasalahan matematika dapat diselesaikan karena kemampuan representasi mampu membantu siswa dalam membuat persamaan matematika. Persamaan matematika merupakan salah satu indikator kemampuan representasi. Indikator kemampuan representasi yang diungkapkan oleh Minarni, Napitupulu, dan Husein (2016) meliputi menyajikan permasalahan matematika menggunakan gambar, diagram, grafik, atau tabel (representasi gambar); menggunakan kata-kata (representasi verbal); dan menggunakan persamaan, model, atau simbol matematika (representasi simbolik). Indikator tersebut akan digunakan dalam penelitian ini untuk mengukur seberapa baik kemampuan representasi matematis siswa. Arnidha (2016) juga menjabarkan hal-hal yang diukur selama proses kemampuan representasi diantaranya: 1) representasi mampu menerjemahkan masalah ke dalam bentuk yang baru; 2) representasi mampu mengubah simbol atau diagram atau kata-kata; dan 3) representasi mampu menerjemahkan suatu masalah agar maknanya lebih jelas.

Siswa dengan kemampuan representasi yang baik mampu memenuhi ketiga indikator. Fakta menunjukkan bahwa kemampuan representasi tergolong kategori rendah sebesar 45,1\% pada aspek simbol berdasarkan penelitian terdahulu yang dilakukan oleh Fajriah, Utami, dan Mariyam (2020). Hal yang sama juga dilakukan oleh Ramadhan dan Aini (2021) dalam penelitiannya yang menunjukkan bahwa kemampuan representasi pada aspek simbol masih kurang dikarenakan siswa tidak teliti membaca soal. Selanjutnya, berdasarkan penelitian terdahulu yang dilakukan oleh Mulyadi dan Fiangga (2021) menunjukkan bahwa siswa memiliki kemampuan representasi sedang yakni siswa tersebut belum memenuhi indikator representasi gambar. Dengan demikian, siswa belum menggunakan kemampuan representasinya dalam menyelesaikan masalah. Hal demikian diperkuat oleh penelitian Herdiman, dkk (2018) yang menunjukkan bahwa kemampuan representasi matematis siswa untuk indikator kata-kata tergolong rendah yakni $43 \%$, untuk indikator representasi persamaan tergolong kategori sangat rendah yakni $34,75 \%$, dan untuk indikator representasi gambar tergolong kategori sedang yakni 60\%.

Terkait pemaparan di atas dapat dikatakan bahwa kemampuan representasi masih rendah sehingga siswa kesulitan dalam penyelesaian masalah matematika. Oleh karenanya, peneliti bermaksud melakukan penelitian untuk mengetahui kemampuan representasi matematis pada materi kesebangunan siswa kelas X. Penelitian ini diharapkan mampu digunakan sebagai rujukan oleh guru dalam mengajar untuk fokus mengembangkan kemampuan representasi matematis siswa.

\section{METODE PENELITIAN}

Penelitian ini menggunakan metode deskriptif kualitatif. Penelitian ini dilakukan bertujuan untuk mendeskripsikan kemampuan representasi matematis siswa pada materi kesebangunan. Penelitian deskriptif merupakan metode yang digunakan untuk mendeskripsikan suatu kejadian. Rahmayani dan Effendi (2019) juga memaparkan bahwa penelitian ini bertujuan menggambarkan fenomena yang sedang berlangsung maupun sudah lampau.

Open Access: https://ejournal.unma.ac.id/index.php/educatio 
Subjek dalam penelitian ini adalah siswa kelas X di salah satu Madrasah Aliyah di kecamatan Purwasari, Kabupaten Karawang sebanyak 3 siswa yang dipilih dari 10 siswa. Subjek penelitian ditentukan menggunakan purposive sampling. Purposive sampling adalah teknik menentukan suatu sampel dengan pertimbangan tertentu. Instrumen yang digunakan adalah instrumen tes tertulis kemampuan representasi matematis. Instrumen tes memuat sebanyak 5 soal uraian materi kesebangunan dan sudah divalidasi dari penelitian Kusumah (2016) dengan indikator-indikatornya memenuhi soal kemampuan representasi matematis. Guna mengetahui kemampuan representasi matematis yang dimiliki siswa, peneliti memberikan skor terhadap jawaban yang diberikan oleh siswa untuk kemudian dianalisis berdasarkan kategori kemampuan representasi matematis. Subjek dipilih berdasarkan kategori tinggi, sedang, dan rendah sebanyak 1 subjek pada masing-masing kategori untuk dianalisis bagaimana kemampuan representasi matematis siswa.

Teknik analisis data yang digunakan dalam penelitian ini meliputi pengumpulan data, penyajian data, reduksi data, dan penarikan kesimpulan. Berdasarkan hasil tes, kemampuan representasi matematis siswa ditinjau berdasarkan kategori tinggi, sedang, dan rendah. Pedoman kategori tersebut dikelompokkan berdasarkan Azwar (dalam Sapitri dan Ramlah, 2019) yang tersaji pada tabel 1.

Tabel 1 Kategori Kemampuan Representasi Matematis

\begin{tabular}{cc}
\hline Kategori & Kriteria Nilai \\
\hline Tinggi & $x \geq M+s d$ \\
Sedang & $M-s d \leq x<M+s d$ \\
Rendah & $x \leq M-s d$ \\
\hline
\end{tabular}

Keterangan:

$x$ : nilai siswa

$M:$ mean ideal

$s d:$ standar deviasi ideal

\section{HASIL DAN PEMBAHASAN}

Hasil penelitian ini diperoleh berdasarkan tes kemampuan representasi matematis siswa berupa nilai. Hal ini merupakan langkah awal dalam penelitian ini yakni pengumpulan data menggunakan instrumen tes kemampuan representasi matematis siswa dalam materi kesebangunan. Hasil tes kemampuan representasi matematis siswa tersaji pada tabel 2 .

Tabel 2 Hasil Tes Kemampuan Representasi Matematis Siswa

\begin{tabular}{ccccc}
\hline Jumlah Siswa & Nilai Maksimal & Nilai Minimal & Rata-rata & Standar Deviasi \\
\hline 10 & 72 & 23 & 53 & 16 \\
\hline
\end{tabular}

Ditinjau dari tabel 2 diperoleh bahwa beberapa siswa sudah mampu memenuhi Kriteria Ketuntasan Minimum (KKM) untuk kelas X di sekolah tersebut yakni 66. Siswa memperoleh rata-rata 53 dan standar deviasi 16 dengan nilai maksimal adalah 72 dan nilai minimal adalah 23. Hal ini menunjukkan beberapa siswa di sekolah tersebut masih ada yang belum mampu memenuhi kriteria ketuntasan minimum. Adapun kemampuan representasi matematis siswa tergolong kategori sedang, artinya siswa sudah cukup mampu menyelesaikan soal tes kemampuan representasi matematis pada materi kesebangunan. Kategori kemampuan representasi matematis siswa kelas X di sekolah ini diperoleh berdasarkan Azwar (2006) yang tersaji pada tabel 3.

Tabel 3 Kategori Kemampuan Representasi Matematis

\begin{tabular}{cccc}
\hline Kategori & Kriteria Nilai & Jumlah Siswa & Persentase \\
\hline Tinggi & $x \geq 69$ & 2 & $20 \%$
\end{tabular}




$\begin{array}{cccc}\text { Sedang } & 37 \leq x<69 & 5 & 50 \% \\ \text { Rendah } & x<37 & 3 & 30 \% \\ \text { Total } & 10 & 100 \%\end{array}$

Ditinjau dari tabel 3 diperoleh bahwa kemampuan representasi matematis siswa pada kategori tinggi memperoleh persentase sebesar $20 \%$ sebanyak 2 siswa, kategori sedang memperoleh persentase sebesar 50\% sebanyak 5 siswa, dan kategori rendah memperoleh persentase sebesar 30\% sebanyak 3 siswa. Perolehan kategori terbesar ditunjukkan pada kategori sedang dengan peroleh persentase yakni 50\% yang terdiri dari 5 siswa. Hal ini menunjukkan sebagian besar siswa memiliki kemampuan representasi matematis pada materi kesebangunan.

Tes kemampuan representasi matematis memuat 5 soal uraian pada materi kesebangunan yang dengan indikator-indikatornya memenuhi soal kemampuan representasi matematis. Hasil analisis jawaban siswa diambil berdasarkan jawaban tiap indikator pada kategori rendah, sedang, dan tinggi.

Indikator kemampuan representasi verbal atau kata-kata diukur dalam soal nomor 1. Dalam soal nomor 1, siswa diharapkan mampu menunjukkan dua bangun yang kongruen melalui model bangun datar yang diberikan beserta alasannya. Jawaban yang diberikan siswa tersaji pada gambar 1.

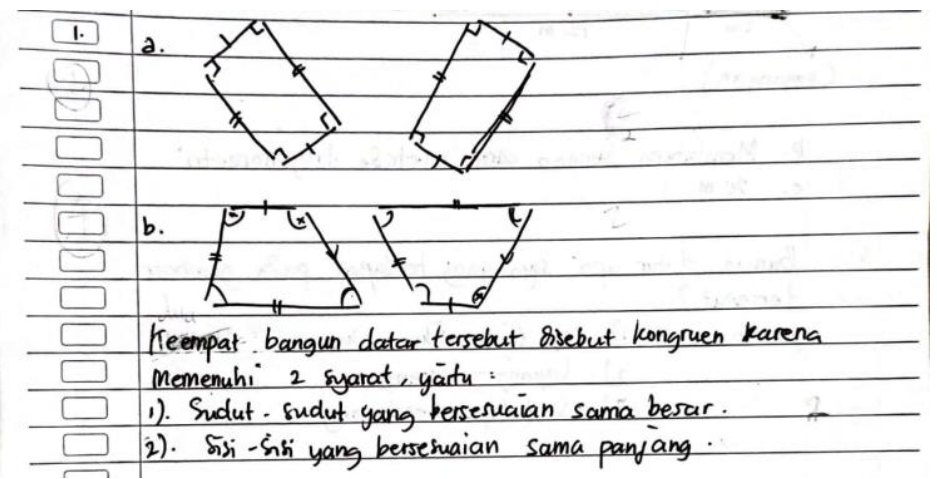

Gambar 1. Jawaban Siswa Kategori Rendah

Ditinjau dari gambar 1, terlihat bahwa siswa dapat menjawab menunjukkan bangun-bangun datar yang kongruen dengan menggambarkan ulang bangun-bangun datar pada soal. Selain itu, siswa tersebut juga menyertakan alasannya melalui kata-kata. Hal tersebut ditunjukkan berdasarkan jawaban yang dituliskan siswa yakni 1) Sudut-sudut yang bersesuaian sama besar dan 2) Sisi-sisi yang bersesuaian sama panjang.

Siswa yang mampu menyatakan permasalahan matematika dengan kata-kata dapat dikatakan sudah mampu memenuhi indikator kemampuan representasi verbal atau kata-kata. Dahlan dan Juandi (2011) menyatakan kata-kata tersebut dapat diungkapkan karena berasal dari hasil pemikirannya terhadap gambar tersebut.

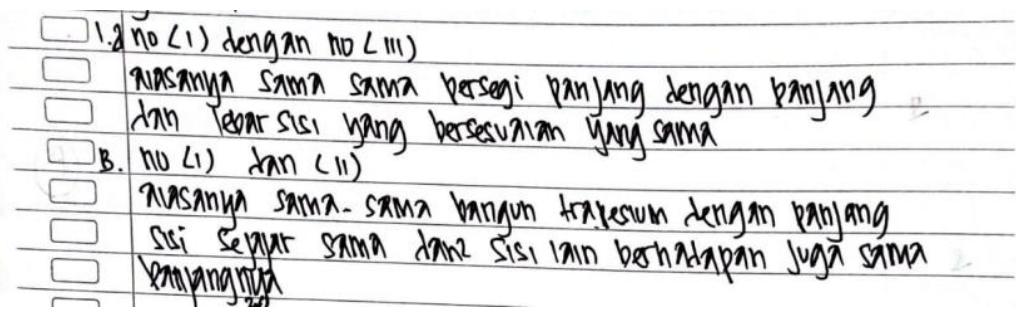

Gambar 2. Jawaban Siswa Kategori Sedang

Ditinjau dari gambar 2, terlihat bahwa siswa mampu menunjukkan bangun-bangun datar yang kongruen namun tidak menggambarkannya. Berbeda dengan jawaban siswa kategori rendah yang menyertakan gambar, siswa ini menyertakan alasannya melalui kata-kata. Hal tersebut ditunjukkan 
berdasarkan jawaban yang dituliskan siswa yakni "Alasnya sama-sama persegi panjang dengan panjang dan lebar sisi yang bersesuaian sama panjangnya".

Meski siswa tidak menyertakan gambar, siswa mampu menunjukkan bangun datar tersebut kongruen yakni pada soal 1 poin a adalah no (i) dan no (iii) serta soal 1 poin b adalah no (i) dan no (ii). Artinya, siswa sudah mampu memenuhi indikator kemampuan representasi verbal atau kata-kata karena alasannya yang benar. Hal ini didukung oleh Hadi (2018) yang menyatakan bahwa siswa mampu merepresentasikan idenya menggunakan tulisan dengan baik karena pemahaman siswa terhadap materi tersebut.

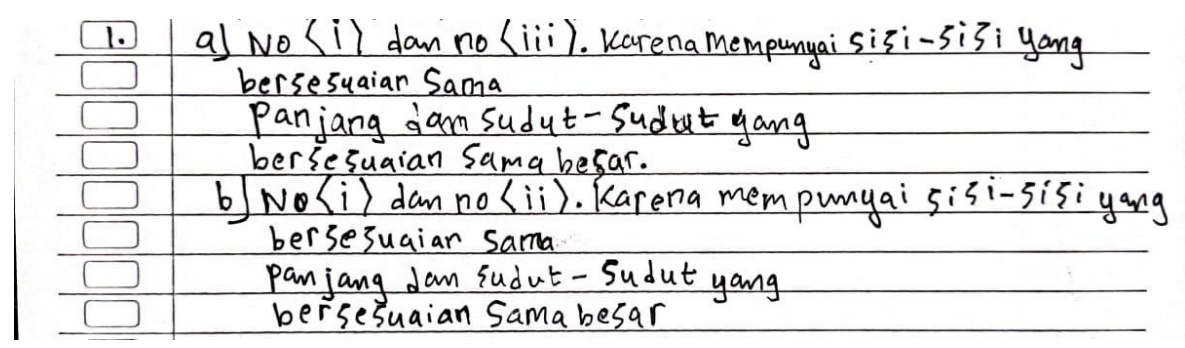

Gambar 3. Jawaban Siswa Kategori Tinggi

Ditinjau dari gambar 3, terlihat bahwa siswa mampu menunjukkan bangun-bangun datar yang kongruen namun tidak menggambarkannya. Hal ini sama dengan siswa dengan kategori sedang. Meski demikian, siswa menyertakan alasan mengapa bangun-bangun datar tersebut kongruen melalui kata-kata dan menyebutkan bangun-bangun datar yang kongruen sesuai nomor yang dicantumkan pada soal.

Alasan tersebut ditunjukkan dari jawaban yang dikerjakan oleh siswa yakni teletak dalam jawaban untuk soal nomor 1 poin a, siswa menuliskan "No (i) dan no (iii), karena mempunyai sisi-sisi yang bersesuaian sama panjang dan sudut-sudut yang bersesuaian sama besar" dan nomor 1 poin b siswa menuliskan "No (i) dan no (ii), karena mempunyai sisi-sisi yang bersesuain sama panjang dan sudut-sudut yang bersesuaian sama besar". Artinya, siswa sudah mampu memenuhi indikator kemampuan representasi verbal atau kata-kata menggunakan alasan yang benar karena siswa memahami materi tersebut. Sejalan dengan pernyataan Cahani dan Effendi (2019) bahwa siswa yang sudah memahami materi tertentu mampu menjelaskan menggunakan kata-katanya sendiri.

Indikator kemampuan representasi gambar diukur dalam soal nomor 2. Dalam soal nomor 2, siswa diharapkan mampu menyajikan kembali informasi dari suatu representasi kata-kata atau soal cerita ke dalam bentuk representasi gambar. Hal ini diukur dalam soal nomor 2 poin a. Siswa diarahkan untuk membuat gambar pigura dengan bingkai di tepinya dari suatu pigura yang panjang dan lebarnya $30 \times 20 \mathrm{~cm}$ dan ditambah bingkai dengan lebarnya $5 \mathrm{~cm}$. Jawaban yang diberikan siswa tersaji pada gambar 4 .

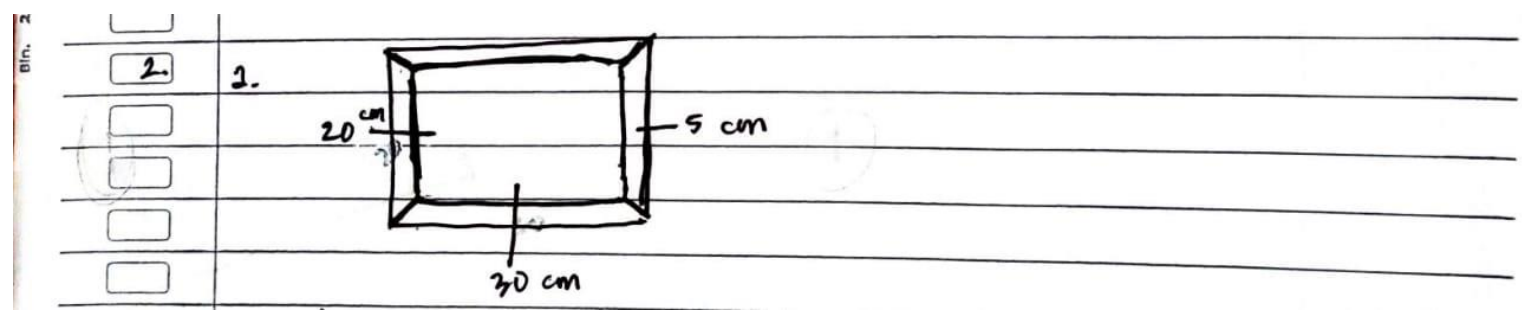

Gambar 4. Jawaban Siswa Kategori Rendah

Ditinjau dari gambar 4, terlihat bahwa siswa mampu membuat gambar pigura yang diberi bingkai di tepinya. Gambar yang diberikan sangat realistis, namun siswa menyatakan gambar bingkai sebagai bentuk trapesium. Telihat dalam jawabannya untuk nomor 2 poin b yang akan ditunjukkan pada gambar selanjutnya. Meski demikian, siswa sudah menunjukkan lebar bingkai dengan benar yakni $5 \mathrm{~cm}$. 
Siswa sudah menunjukkan panjang pigura, namun yang ditunjukkannya salah yakni panjangnya $30 \mathrm{~cm}$ sebagai tepi dalam yang seharusnya sebagai tepi luar pigura. Begitupun pada lebar pigura, siswa salah menunjukkannya yakni lebarnya $20 \mathrm{~cm}$ sebagai tepi dalam yang seharusnya sebagai tepi luar pigura.

Ditinjau dari pemaparan di atas maka didapatkan suatu analisis yakni siswa kurang mampu memenuhi kemampuan representasi gambar. Penyebab kekurangan tersebut karena siswa tidak terbiasa menyajikan masalah matematika dalam bentuk gambar. Pernyataan ini juga didukung oleh Sulistyowati, Kusumah, dan Priatna (2019) bahwa siswa terbiasa menyelesaikan masalah dari informasi dan contoh yang diberikan oleh guru.

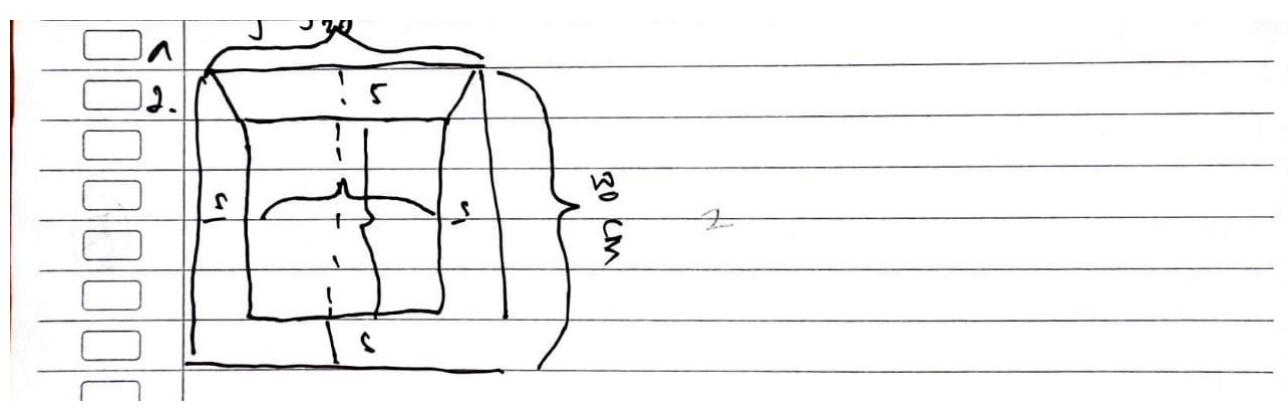

Gambar 5. Jawaban Siswa Kategori Sedang

Ditinjau dari gambar 5, terlihat bahwa siswa mampu membuat gambar pigura yang diberi bingkai dengan menunjukkan ukuran pigura dan bingkai secara benar. Terlihat dalam jawaban siswa yang menunjukkan panjang pigura tepi luar yakni $30 \mathrm{~cm}$ dan lebar pigura tepi luar yakni $20 \mathrm{~cm}$ serta menunjukkan lebar setiap bingkai yakni $5 \mathrm{~cm}$.

Ditinjau dari pemaparan di atas maka didapatkan suatu analisis yakni siswa sudah mampu memenuhi kemampuan representasi gambar. Permasalahan matematika pada nomor 2 poin a dapat diselesaikan karena siswa mampu menggunakan representasi yang tepat yakni representasi gambar. Hal ini didukung oleh pernyataan Lette dan Manoy (2019) bahwa siswa yang memiliki kemampuan representasi mampu mengubah pernyataan matematika menggunakan representasi yang tepat untuk memperoleh solusi masalah.

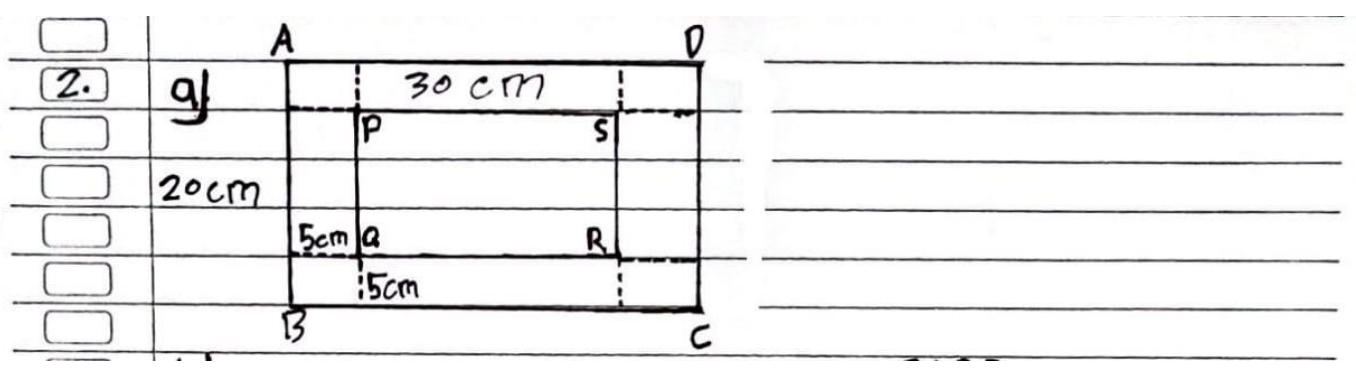

Gambar 6. Jawaban Siswa Kategori Tinggi

Ditinjau dari gambar 6, terlihat bahwa siswa mampu membuat gambar pigura yang diberi bingkai dan menunjukkan ukuran pigura dan bingkai dengan benar. Terlihat dalam jawaban siswa yang menunjukkan panjang pigura tepi luar yakni $30 \mathrm{~cm}$. Meski terlihat $30 \mathrm{~cm}$ menunjukkan tepi dalam, siswa menyatakan bahwa $30 \mathrm{~cm}$ adalah panjang AD. Siswa juga menunjukkan lebar pigura tepi luar yakni $20 \mathrm{~cm}$ dan menunjukkan lebar bingkai yakni $5 \mathrm{~cm}$.

Ditinjau dari pemaparan di atas maka didapatkan suatu analisis yakni siswa sudah mampu memenuhi kemampuan representasi gambar. Kemampuan tersebut dimiliki karena siswa tergolong pada kategori tinggi sehingga siswa mampu menyajikan informasi dari soal ke dalam bentuk gambar. Pernyataan tersebut didukung oleh Nurpadilah, Rohaeti, dan Afrilianto (2018) bahwa siswa dengan kemampuan dasar yang tinggi akan mampu merepresentasikan masalah matematika dalam bentuk gambar dengan tepat. 
Indikator kemampuan representasi simbolik diukur pada soal nomor 2. Pada soal nomor 2, siswa diharapkan mampu menggunakan model atau persamaan matematika dari soal cerita untuk menjawab apakah bangun datar yang disajikannya pada gambar nomor 2 poin a sebangun. Persamaan matematika yang diharapkan mampu disajikan oleh siswa yakni perbandingan sisi-sisi yang bersesuaian atau $\frac{\text { panjang sisi tepi luar }}{\text { panjang sisi tepi dalam }}$. Jawaban yang diberikan siswa tersaji pada gambar 7 .

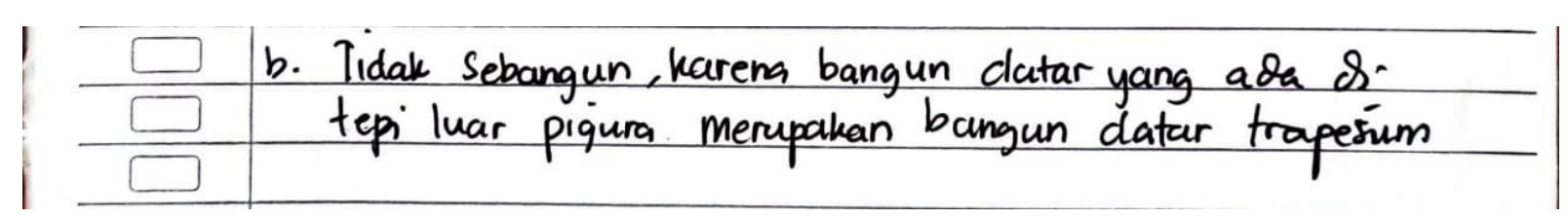

Gambar 7. Jawaban Siswa Kategori Rendah

Ditinjau dari gambar 7, terlihat bahwa siswa tidak menunjukkan model matematikanya untuk menjawab soal ini. Sesuai dengan gambar 4, gambar bangun datar yang siswa buat untuk menjawab soal nomor 2 poin a adalah salah karena siswa menyatakan bingkai pigura sebagai bangun datar trapesium. Selain itu, pada materi kesebangunan yang menjadi acuan dalam pengerjaan masalah tersebut adalah terdapat 2 bangun datar yaitu persegi panjang tepi dalam (persegi panjang yang berada di dalam bingkai) dan persegi panjang tepi luar (persegi panjang yang diberi bingkai). Oleh karenanya, untuk menjawab masalah tersebut tidak perlu diketahui bentuk bangun datar pada bingkai.

Ditinjau dari pemaparan di atas maka didapatkan suatu analisis yakni siswa belum mampu memenuhi kemampuan representasi simbolik. Penyebabnya karena siswa tidak teliti dalam menyajikan masalah matematika dalam bentuk gambar sehingga siswa tidak mampu menyajikan bentuk model atau persamaan. Pernyataan ini didukung oleh Hijriani, Rahardjo, dan Rahardi (2018) bahwa ketidaktelitian siswa dalam menyelesaikan solusi matematika menjadi penyebab siswa tidak mampu menyajikan representasi dengan benar.

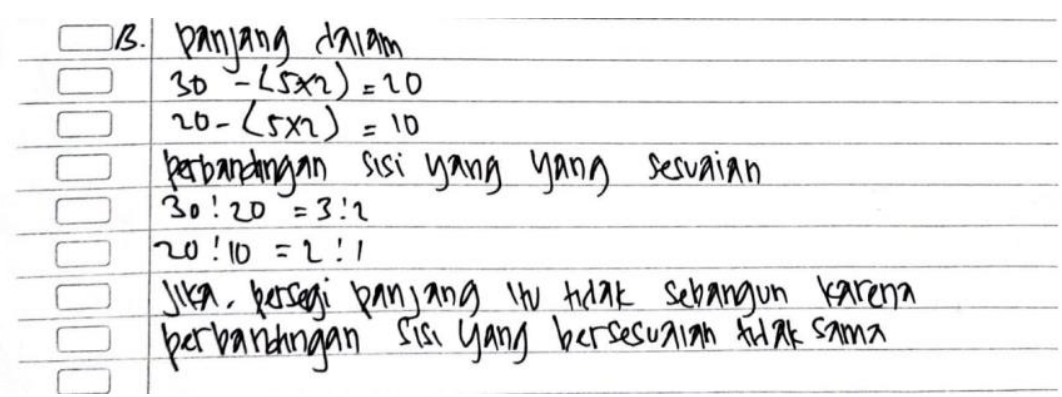

Gambar 8. Jawaban Siswa Kategori Sedang

Ditinjau dari gambar 8, terlihat bahwa siswa tidak membuat model matematika untuk memberikan jawaban dalam soal ini. Siswa melakukan perhitungan dan alasan yang benar, namun alasan tersebut kurang diperkuat dengan model atau persamaan matematika sesuai harapan. Meski demikian, siswa menyajikan model matematika langsung dalam bentuk angka yakni $\frac{30}{20}=\frac{3}{2}$ dan $\frac{20}{10}=\frac{2}{1}$. Siswa menyatakan bahwa ia lupa menyebutkan sisi-sisi yang bersesuaian sehingga tidak mampu menuliskan persamaan matematikanya.

Ditinjau dari pemaparan di atas maka didapatkan suatu analisis yakni siswa belum memenuhi kemampuan representasi simbolik. Penyebabnya karena siswa tidak menuliskan apa yang ditanyakan, sehingga siswa tidak memahami masalah yang ditanyakan dan mengakibatkan tidak menyebutkan sisi-sisi yang bersesuaian pada jawabannya. Pernyataan ini didukung oleh Yusnia dan Fitriyani (2011) bahwa siswa yang tidak menuliskan yang diketahui dan dijawab mengalami kesulitan dalam memaknai masalah yang ditanyakan. 


\begin{tabular}{|c|c|}
\hline$\square$ & b] Persegipanjang ABCD dan persegi panjang PQRS memilici sudut yang \\
\hline$\square$ & bersesuaian sama besar yaitu $90^{\circ}$ 〈sudut siku-siku \\
\hline$\square$ & \\
\hline$\square$ & 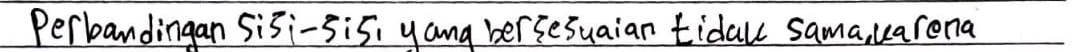 \\
\hline$\square$ & $A B=20^{\circ}=2 \operatorname{dan} A D=30=3$ \\
\hline$\square$ & $\overline{P Q} \quad \overline{10} \quad P S \quad 20 \quad \overline{2}$ \\
\hline$\square$ & Jadi,pigura tepi luar tidale sebangun dergan pigura tepi dalam. \\
\hline
\end{tabular}

Ditinjau dari gambar 9, terlihat bahwa siswa sudah membuat model matematika yakni perbandingan sisi-sisi yang bersesuaian untuk memberikan jawaban dalam soal ini. Siswa juga melakukan perhitungan dan alasan yang benar dengan menyertakan model matematika untuk memperkuat alasannya. Terlihat dari penyelesaian jawaban yang siswa jabarkan yakni $\frac{A B}{P Q}=\frac{20}{10}=2$ dan $\frac{A D}{P S}=\frac{30}{20}=\frac{3}{2}$, sehingga siswa mampu menyimpulkan bahwa bangun-bangun datar tersebut tidak sebangun.

Ditinjau dari pemaparan di atas maka didapatkan suatu analisis yakni siswa sudah mampu memenuhi kemampuan representasi simbolik. Kemampuannya dalam merepresentasikan ke dalam simbol dikarenakan siswa memahami materi kesebangunan sehingga mampu menggunakan konsep dengan benar. Pernyataan ini didukung oleh Rasid, Hairun, dan Afandi (2016) bahwa penggunaan konsep yang benar mampu membantu siswa mengerjakan soal dengan kemampuannya.

\section{KESIMPULAN}

Berdasarkan hasil analisis di atas dapat disimpulkan bahwa siswa dengan kategori rendah hanya memenuhi satu indikator yakni kemampuan representasi verbal, siswa tidak memenuhi kemampuan representasi gambar dan simbolik karena siswa tidak teliti dan terbiasa menyajikan masalah matematika dalam bentuk gambar sehingga siswa tidak mampu menyajikan bentuk model atau persamaan. Siswa dengan kategori sedang memenuhi dua indikator yakni kemampuan representasi verbal dan gambar, siswa tidak memenuhi kemampuan representasi simbolik karena dalam jawabannya siswa tidak menuliskan apa yang ditanyakan, sehingga siswa tidak memahami masalah yang ditanyakan dan mengakibatkan tidak menyebutkan sisi-sisi yang bersesuaian pada jawabannya. Siswa dengan kategori tinggi mampu memenuhi tiga indikator yakni kemampuan representasi verbal, gambar, dan simbolik karena siswa yang memahami konsep dan materi tertentu dengan benar mampu menyelesaikan masalah matematika menggunakan kata-kata, menyajikan informasi dari soal ke dalam bentuk gambar, maupun menggunakan simbol. Dari hasil penelitian ini diharapkan mampu dijadikan acuan untuk pembelajaran mendatang agar guru mampu fokus mengembangkan kemampuan representasi matematis siswa dalam menyelesaikan masalah.

\section{DAFTAR PUSTAKA}

Absorin, A., \& Sugiman, S. (2018). Eksplorasi Kemampuan Penalaran dan Representasi Matematis Siswa Sekolah Menengah Pertama. Pythagoras: Jurnal Pendidikan Matematika, 13(2), 189-202. https://doi.org/10.21831/pg.v13i2.21249

Annajmi. (2016). Peningkatan Kemampuan Representasi Matematik Siswa SMP melalui Metode Penemuan Terbimbing Berbantuan Software Geogebra di SMP N 25 Pekanbaru. Jurnal Ilmiah Edu Research, 5(2), $67-74$.

Arnidha, Y. (2016). Peningkatan Kemampuan Representasi Matematis Melalui Model Pembelajaran Kooperatif Think Pair Share. Jurnal E-DuMath, 2(1), 128-137. https://core.ac.uk/reader/229584120

Cahani, K., \& Effendi, K. N. S. (2019). Kemampuan Pemahaman Konsep Matematika Siswa SMP Kelas IX Pada Materi Bangun Datar Segiempat. Prosiding Seminar Nasional Matematika Dan Pendidikan Matematika Sesiomadika, 120-128. http://journal.unsika.ac.id/index.php/sesiomadika 
Dahlan, J. A., \& Juandi, D. (2011). Analisis Representasi Matematik Siswa Sekolah Dasar dalam Penyelesaian Masalah Matematika Kontekstual. JPMIPA: Jurnal Pengajaran Matematika Dan Ilmu Pengetahuan Alam, 16(1).

Fajriah, N., Utami, C., \& Mariyam. (2020). Analisis Kemampuan Representasi Matematis Siswa Smp pada Materi Statistika. Jerr: Journal of Educational Review and Research, 3(1), 14-24. https://doi.org/10.33592/pelita.vol10.iss1.373

Hadi, S. (2018). Representasi Matematis Pemahaman Geometri Siswa MI. Ibriez, 3(2), 88-98.

Handayani, H., \& Juanda, R. Y. (2018). Profil Kemampuan Representasi Matematis Siswa Sekolah Dasar Di Kecamatan Sumedang Utara. Primary: Jurnal Pendidikan Guru Sekolah Dasar, 7(2), 211-217. https://doi.org/10.33578/jpfkip.v7i2.6265

Hendrayana, A. (2017). Pengaruh Pembelajaran Pendekatan Rigorous Mathematical Thinking (RMT) terhadap Pemahaman Konseptual Matematis Siswa SMP. Jurnal Riset Pendidikan Matematika, 4(2), 186199. https://doi.org/10.21831/jrpm.v4i2.15385

Herdiman, I., Jayanti, K., Pertiwi, K. A., \& Naila N., R. (2018). Kemampuan Representasi Matematis Siswa SMP pada Materi Kekongruenan dan Kesebangunan. Jurnal Elemen, 4(2), 216. https://doi.org/10.29408/jel.v4i2.539

Hijriani, L., Rahardjo, S., \& Rahardi, R. (2018). Deskripsi Representasi Matematis Siswa SMP dalam Menyelesaikan Soal PISA. Jurnal Pendidikan: Teori, Penelitian, Dan Pengembangan, 3(5), 603-607. http://journal.um.ac.id/index.php/jptpp/

Huda, U., Musdi, E., \& Nari, N. (2019). Analisis Kemampuan Representasi Matematis Siswa dalam Menyelesaikan Soal Pemecahan Masalah Matematika. Jurnal Ta'dib: Jurnal Pendidikan Islam, 22(1).

Inayah, S., \& Nurhasanah, G. A. (2019). Pengaruh Kemampuan Representasi Matematis Siswa Terhadap Kepercayaan Dirinya. Jurnal Penelitian Dan Pembelajaran Matematika, 12(1), 17-31. https://doi.org/10.30870/jppm.v12i1.4852

Lette, I., \& Manoy, J. T. (2019). Representasi Siswa SMP dalam Memecahkan Masalah Matematika ditinjau dari Kemampuan Matematika. MATHEdunesa, 8(3), 574-580.

Minarni, A., Napitupulu, E. E., \& Husein, R. (2016). Mathematical Understanding and Representation Ability of Public Junior High School in North Sumatra. Journal on Mathematics Education, 7(1), 43-56.

Mulyadi, N. A., \& Fiangga, S. (2021). Analisis Kemampuan Representasi Siswa Dalam Menyelesaikan Soal Materi Bangun Datar. Jurnal Ilmiah Soulmath: Jurnal Edukasi Pendidikan Matematika, 9(2), 143-152. https://doi.org/10.25139/smj.v9i2.3938

Najiha Nadia, L., Budi Waluyo, S., \& Isnarto. (2017). Analisis Kemampuan Representasi Matematis Ditinjau dari Self Efficacy Peserta Didik melalui Inductive Discovery Learning. Ujmer: Unnes Journal of Mathematics Education Research, 6(2), 242-250. http://journal.unnes.ac.id/sju/index.php/ujmer

NCTM. (2000). Principles and Standards for School Mathematics. VA: The National Council of Teachers of Mathematics.

Nurpadilah, E., Rohaeti, E. E., \& Afrilianto, M. (2018). Kemampuan Representasi Matematik pada Materi Segi Empat Siswa SMP Kelas VII. Jurnal Pembelajaran Matematika Inovatif, 1(4).

Rahmayani, S. R., \& Effendi, K. N. S. (2019). Kemampuan Komunikasi Matematis Siswa SMP pada Materi Himpunan. Judika (Jurnal Pendidikan Unsika), 7(1), 10-18.

Ramadhan, M. I., \& Aini, I. N. (2021). Analisis Kemampuan Representasi Matematis Siswa Kelas VIII dalam Menyelesaikan Soal Matematika pada Materi Bangun Ruang. JPMI: Jurnal Pembelajaran Matematika Inovatif, 4(4), 975-984. https://doi.org/10.22460/jpmi.v4i4.975-984 
Rasid, S., Hairun, Y., \& Afandi, A. (2016). Penerapan Model Pembelajaran Team Assisted Individuallization (TAI) ditinjau dari Kemampuan Pemahaman Matematis Siswa pada Materi Trigonometri. Delta-Pi: Jurnal Matematika Dan Pendidikan Matematika, 5(1).

Sapitri, I., \& Ramlah, R. (2019). Kemampuan Representasi Matematis dalam Meyelesesaikan Soal Kubus dan Balok pada Siswa SMP. Prosiding Seminar Nasional Matematika Dan Pendidikan MAtematika Sesiomadika, 829-835.

Sulistyowati, R. K., Kusumah, Y. S., \& Priatna, B. A. (2019). Peningkatan Kemampuan Representasi Matematis melalui Pembelajaran Collaborative Problem Solving. Jurnal Pendidikan Matematika, 13(2), $153-162$.

Yusnia, D., \& Fitriyani, H. (2010). Identifikasi Kesalahan Siswa Menggunakan Newman's Error Analysis (NEA) pada Pemecahan Masalah Operasi Hitung Bentuk Aljabar. Prosiding Seminar Nasional \& Internasional UNIMUS, 78-83. 